\title{
IN VITRO EVALUATION OF AEGLE MARMELOS LEAF EXTRACTS ON FOOT ULCER AND URINARY TRACT INFECTED PATHOGENS FROM DIABETIC PATIENTS
}

\author{
MUJAWAR SALMA BEGUM HUSSAIN, MURIGENDRA B HIREMATH*
}

Department of Biotechnology and Microbiology, Karnatak University, Dharwad, Karnataka, India. Email: murigendra@kud.ac.in; murigendra@gmail.com

Received: 29 November 2019, Revised and Accepted: 16 December 2019

\section{ABSTRACT}

Objective: The objective of the study was to evaluate the effect of leaf extracts on foot ulcer and urinary tract pathogens from patients having diabetes.

Methods: The pus and urine sample from the patients having diabetes were collected and cultured on nutrient agar plates. The morphological characters were studied for the colonies obtained. Antimicrobial activity of ethanol and aqueous extracts was studied for Aegle marmelos leaves.

Results: Ethanol extract exhibited good results for both foot ulcer and urinary tract infected pathogens as compared to aqueous extract. Thin-layer chromatography was performed for methanol extract and then was subjected to column chromatography. The fractions obtained were again checked for the antibacterial activity and of three fractions, fraction 1 showed better results for pus and urine pathogens. Fourier-transformed infrared analysis was carried out for fraction 1 of methanol extract for verifying the presence of bioactive compounds.

Conclusion: From the present study, it can be terminated that the bioactive compounds derived from plant extracts can be used for the development of new pharmaceutical drugs to reach out to various therapeutic needs.

Keywords: Medicinal plant, Antimicrobial activity, Aegle marmelos, Thin-layer chromatography, Column chromatography, Fourier-transformed infrared.

(C) 2020 The Authors. Published by Innovare Academic Sciences Pvt Ltd. This is an open access article under the CC BY license (http://creativecommons. org/licenses/by/4. 0/) DOI: http://dx.doi.org/10.22159/ajpcr.2020.v13i1.36514

\section{INTRODUCTION}

More than 45,000 plant species are found in India and thousands among them have been reported to have medicinal properties [1]. The use of phytoconstituents and secondary metabolites is documented in various ancient scriptures for medicament against various ailments since ages due to the richness of Indian floral biodiversity and the medicinal potentials of their extracts [2]. The bioactive compounds found in plants responsible for antimicrobial activity can prevent bacterial infections by various mechanisms to that of commercially available antibiotics and thus may have clinical value in treatment of different strains of resistant microorganism [3]. The leg and foot ulcers are non-healing wounds for longer duration, which occur due to the disintegration in the physiology of legs. This disintegration is usually correlated with venous, arterial, or metabolic factors [4]. Urinary tract infections (UTIs) are very often observed and occur more often in women than in men. Women are more prone to (UTI) infection to that of men due to the proximal location of reproductive and lower urinary tracts. Among factors responsible for the risk of UTI are diabetes, vaginal inflammation, reproductive disorders and urinary bladder, neoplastic diseases, and invasive gynecology surgery $[5,6]$. Aegle marmelos is a medium-sized, armed deciduous tree, commonly known as Bael which belongs to the family Rutaceae. A. marmelos is widely distributed in India and is still growing in most of the countries of Southeast Asia. Leaves, fruits, stems, and roots of the Bael tree at all the stages of maturity are extensively used as ethno medicines against various human diseases [7]. The objective of this study was to evaluate the potential of plant on multi-drug resistant bacteria isolated from diabetic foot ulcers and UTIs.

\section{METHODS}

\section{Collection of samples}

The pus and urine samples from diabetic patients were collected from fifty affected patients from Ramanagoudar Multispeciality Hospital and
Civil Hospital, Dharwad district, Karnataka, India. The urine samples were collected in an ice-cold condition by adding boric acid at final bacteriostatic concentration of $1.8 \%$ without delay [8] and pus samples were collected in form of cotton swabs and bandages in locking bags. Samples were then transported to Microbiology Laboratory, Karnatak University, Dharwad, collected urine samples were streaked and pus samples were swabbed on nutrient agar plates. Plates were incubated at $37^{\circ} \mathrm{C}$ for $24 \mathrm{~h}$. After incubation, the individual colonies showing different colony morphological characteristics were streaked on different selective agar plates. The isolated pathogens were stored in agar plates for further biochemical analysis.

\section{Biochemical test for isolated pathogens}

The conventional microbiological and biochemical procedures were used to identify and confirmed the isolated pathogens followed by the Department of Microbiology, Karnatak University, Dharwad. Many several biochemical tests such as gram staining, motility test, citrate utilization test, catalase test, oxidase test, indole production test, methyl red test, Voges-Proskauer test, and urease test were used for the confirmation of the test pathogens followed by $[9,10]$.

\section{Collection of plant material}

The plant $A$. marmelos leaves were collected from the Dharwad region early morning between $7 \mathrm{am}$ and $8.30 \mathrm{am}$ in the month of February. The leaves were identified and authenticated by Dr. Kotresha K, Department of Botany, Karnatak Science College, Dharwad, Karnataka. Fresh collected leaves were washed with water and dried completely to obtain fine powder. The plant material in the form of powder was maintained at room temperature in airtight containers for further studies.

Preparation of plant extracts

About $100 \mathrm{~g}$ dried leaves were coarsely powdered and subjected to extraction by Soxhlet extractor. The extraction was done with different solvents in their increasing order of polarity such as ethanol and 
aqueous. All the extracts obtained were concentrated under reduced pressure at $40^{\circ} \mathrm{C}$ using a rotary vacuum evaporator and evaporated to complete dryness.

\section{Antimicrobial activity of selected plant extract against the isolated} pathogens

Antimicrobial activity test was performed by cup plate method. The organisms isolated from diabetic patients having foot ulcer and UTI were spread plated on sterile Mueller-Hinton agar plates. Wells of 4-5 mm in diameter were made aseptically using cork borer, and 15-20 $\mu \mathrm{l}$ of aqueous and ethanolic extract of plant were inoculated. The result was calculated in terms of the zone of inhibition in millimeters. For every concentration, three sets were performed to confirm the activity and standard drug amoxicillin at $250 \mathrm{mg}$ was made use for the comparison.

\section{Thin-layer chromatography (TLC)}

Approximately $4 \mathrm{~g}$ of ethanol extract was dissolved in $100 \mathrm{ml}$ of double-distilled water, which showed good solubility, further it was filtered using normal filter paper. Completely dissolved extract was loaded on pre-coated TLC plate, about 1.5-2.0 cm line was drawn with a pencil from the bottom in the plate and capillary tubes were used to load the sample at approximately $1.5 \mathrm{~cm}$ distance between them and methanol was used as the solvent system for TLC.

\section{Column chromatography}

Gel binding for column chromatography was carried out using $4 \mathrm{~g}$ of ethanol extract in double-distilled water with $1 \mathrm{~g}$ of silica (mesh size 60-120) and internal diameter $-30 \mathrm{~cm}$; gel loading was done approximately up to $18 \mathrm{~cm}$ in an borosil column. Methanol solvent was used as mobile phase.

\section{Fourier-transformed infrared (FT-IR)}

FT-IR analysis was performed to investigate the presence of the functional group in the ethanol leaves extract of A. marmelos plant, which was carried out and standardized at the USIC Department, Karnatak University, Dharwad. The samples were prepared using spectroscopic pure $\mathrm{KBr}$ (5:95); pellets were fixed in the sample holder and analyzed. FT-IR analysis was done on Shimadzu 8400 S spectrophotometer (Shimadzu Corporation, Japan) in the mid-IR region of $400-4000 \mathrm{~cm}^{-1}$ with 16 scan speeds.

\section{Statistical analysis}

The results obtained were expressed as mean \pm SD. One-way analysis of variance was used to analyze the variation.

\section{RESULTS}

Identification of urinary tract infected pathogens and foot ulcer bacterial pathogens

The pus samples of diabetic foot ulcers were found to be Staphylococcus aureus, Escherichia coli, Bacillus subtilis, Pseudomonas aeruginosa, Proteus vulgaris, and Enterobacter aerogenes, whereas E. coli, P. aeruginosa, B. subtilis, E. aerogenes, P. vulgaris, S. aureus, and Klebsiella pneumoniae were found in the urine samples of diabetic patients (Table 1).

Antimicrobial activity of leaves of $A$. marmelos plant extracts against foot ulcer and urinary tract isolates

The ethanolic and aqueous extracts of leaves of the plant $A$. marmelos were subjected for the antimicrobial activity against foot ulcer pathogens and urinary tract infected pathogens. In this study, ethanolic extract showed good results for both urinary tract and foot ulcer pathogens to that of aqueous extract when compared with standard drug amoxicillin. Ethanol extract showed the highest zone of inhibition in P. aeruginosa $(22.5 \pm 0.26)$ and lowest in E. aerogenes (14.1 \pm 0.31$)$ at the concentration of $200 \mathrm{mg} / \mathrm{ml}$ for foot ulcer pathogens, respectively, whereas ethanol extract for urinary tract pathogens showed maximum inhibitory zone for $B$. subtilis $(23.5 \pm 0.33)$ and minimum zone of inhibition for K. pneumoniae $(10.3 \pm 0.10)$ at $200 \mathrm{mg} / \mathrm{ml}$ (Tables 2-5).

TLC

In this TLC, ethanolic extract of leaves of the plant A. marmelos showed three different bands with $\mathrm{Rf}$ value $0.94,0.81$, and 0.72 , respectively,

Table 1: Morphological and biochemical characteristics of the isolated pathogens

\begin{tabular}{|c|c|c|c|c|c|c|c|}
\hline Tests & $\begin{array}{l}\text { Staphylococcus } \\
\text { aureus }\end{array}$ & $\begin{array}{l}\text { Klebsiella } \\
\text { pneumoniae }\end{array}$ & $\begin{array}{l}\text { Pseudomonas } \\
\text { aeruginosa }\end{array}$ & $\begin{array}{l}\text { Bacillus } \\
\text { subtilis }\end{array}$ & $\begin{array}{l}\text { Proteus } \\
\text { vulgaris }\end{array}$ & $\begin{array}{l}\text { Enterobacter } \\
\text { aerogenes }\end{array}$ & $\begin{array}{l}\text { Escherichia } \\
\text { coli }\end{array}$ \\
\hline Gram's stain & + & - & - & + & - & - & - \\
\hline Motility & NM & NM & M & M & M & M & M \\
\hline Catalase & + & + & + & + & + & + & + \\
\hline Citrate & + & + & + & + & + & $+\mathrm{W}$ & - \\
\hline Oxidase & - & - & + & + & - & - & - \\
\hline Indole production & - & - & - & - & + & - & + \\
\hline Vogues-Proskauer & + & + & - & + & - & + & - \\
\hline Glucose fermentation & + & + & - & + & + & + & + \\
\hline Lactose fermentation & + & + & - & + & - & + & + \\
\hline Starch hydrolysis & + & + & - & + & + & + & + \\
\hline $\mathrm{H}_{2} \mathrm{~S}$ production & - & - & - & - & - & + & - \\
\hline Urease & + & + & - & - & + & + & - \\
\hline
\end{tabular}

+: Positive, -: Negative, M: Motile, and NM: Non-motile

Table 2: Activity of ethanol extract against foot ulcer pathogens

\begin{tabular}{lllr}
\hline Isolates & \multicolumn{2}{l}{ Zone of inhibition (mm) } & Amoxicillin (250 mg) \\
\cline { 2 - 4 } & $\mathbf{1 0 0} \mathbf{~} \mathbf{~ g / m l}$ & $\mathbf{1 5 0} \mathbf{~ m g / m l}$ & $\mathbf{2 0 0} \mathbf{~ m g / m l}$ \\
\hline Staphylococcus aureus & $12.2 \pm 0.20$ & $15.3 \pm 0.12$ & $19.3 \pm 0.10$ \\
Escherichia coli & $9.1 \pm 0.51$ & $13.2 \pm 0.34$ & $16.9 \pm 0.21$ \\
Bacillus subtilis & $11.4 \pm 0.21$ & $15.8 \pm 0.85$ & $20.6 \pm 0.66$ \\
Pseudomonas aeruginosa & $15.1 \pm 0.51$ & $19.6 \pm 0.13$ & $22.5 \pm 0.26$ \\
Proteus vulgaris & $12.1 \pm 0.21$ & $14.9 \pm 0.15$ & $18.5 \pm 0.16$ \\
Enterobacter aerogenes & $9.1 \pm 0.30$ & $12.4 \pm 0.21$ & $14.1 \pm 0.31$ \\
\hline
\end{tabular}

Values are mean $\pm S D, n=3$. Results were analyzed using one-way ANOVA. SD: Standard deviation, ANOVA: Analysis of variance 
which was further confirmed with column chromatography to yield different fractions.

\section{Column chromatography}

In this column chromatography, three fractions were obtained from the leaves of the plant A. marmelos (ethanolic extract), further each fraction was studied for antimicrobial activity of the isolated pathogens, which show that fraction 1 was found to be highly effective against foot ulcer and urinary tract pathogens (Tables 6 and 7).

\section{FT-IR}

The FT-IR spectrum of fraction 1 of ethanolic extract of plant $A$. marmelos showed bands at $3463.97 \mathrm{~cm}^{-1}$ corresponds to the stretching vibration of alcohols, the band seen at $2960.92 \mathrm{~cm}^{-1}, 2925.36 \mathrm{~cm}^{-1}, 2852.00 \mathrm{~cm}^{-1}$, $1459.69 \mathrm{~cm}^{-1}$ correspond to the stretching vibrations of alkanes, the band at $2100.48 \mathrm{~cm}^{-1}$ and $1636.26 \mathrm{~cm}^{-1}$ correspond to the stretching vibrations of alkynes and primary amines respectively, the bands at $1577.43 \mathrm{~cm}^{-1}$ and $1424 \mathrm{~cm}^{-1}$ corresponds to aromatic compounds, $1384.92 \mathrm{~cm}^{-1}, 1327.23 \mathrm{~cm}^{-1}$ corresponds to nitro compounds and aromatic amines respectively, the band seen at $1164.65 \mathrm{~cm}^{-1}$ and $546.56 \mathrm{~cm}^{-1}$ corresponds to alkyl halides and band seen at $1088.19 \mathrm{~cm}^{-1}$ corresponds to carboxylic acids, esters and ethers (Fig. 1 and Table 8).

\section{DISCUSSION}

Naturally occurring antimicrobial agents are becoming more popular because of their growing effect against antibiotic-resistant microorganisms and the need for the consumption of natural products for a healthy lifestyle. Before the discovery of modern therapeutics in the post-genomic era natural products and their derivatives has been a successful source of bioactive molecules in medicines [11]. The result obtained from the present study clearly showed that the ethanolic and aqueous extract of the leaves of the plant $A$. marmelos has the antibacterial property against isolated pathogens. The active components present in the plant extracts are responsible for the growth inhibition zone which appears in clear areas around the disc. This antimicrobial activity may be due to the bioactive compounds present in the plant extracts [12]. Secondary metabolites that are derived from plants are either used directly as precursors or as major compounds in the pharmaceutical industries and it is been expected that extracts which show target sites other than the antibiotics will be more active against uropathogens. There are various reports in the literature about the antimicrobial activity of crude extracts prepared from different plants [13-15].

Earlier reports on diabetic foot ulcer were found to contain K. pneumoniae, E. coli, P. aeruginosa, P. vulgaris, S. aureus, and $E$. aerogenes, and the urine samples from diabetic patients were found to be Citrobacter freundii, K. pneumoniae, E. coli, P. aeruginosa, P. vulgaris, $S$. aureus, Salmonella typhi, and E. aerogenes [16]. Parallel results were obtained in the present study; only $C$. freundii was not able to identify in the urine samples, whereas B. subtilis was found to be present in both foot ulcers and a urine sample collected from diabetic patients.

Different extracts of leaves, barks, fruits, and roots of plant $A$. marmelos have been extensively reported to be active against the number of

Table 3: Activity of aqueous extract against foot ulcer pathogens

\begin{tabular}{|c|c|c|c|c|}
\hline \multirow[t]{2}{*}{ Isolates } & \multicolumn{3}{|c|}{ Zone of inhibition (mm) } & \multirow[t]{2}{*}{ Amoxicillin (250 mg) } \\
\hline & $100 \mathrm{mg} / \mathrm{ml}$ & $150 \mathrm{mg} / \mathrm{ml}$ & $200 \mathrm{mg} / \mathrm{ml}$ & \\
\hline Staphylococcus aureus & $9.2 \pm 0.28$ & $12.3 \pm 0.16$ & $15.1 \pm 0.40$ & $20.0 \pm 0.31$ \\
\hline Escherichia coli & $8.1 \pm 0.50$ & $11.1 \pm 0.22$ & $14.1 \pm 0.34$ & $18.4 \pm 0.24$ \\
\hline Bacillus subtilis & $9.8 \pm 0.22$ & $12.8 \pm 0.55$ & $15.6 \pm 0.26$ & $22.3 \pm 0.11$ \\
\hline Pseudomonas aeruginosa & $12.4 \pm 0.41$ & $15.3 \pm 0.11$ & $18.2 \pm 0.44$ & $30.1 \pm 0.55$ \\
\hline Proteus vulgaris & $10.1 \pm 0.11$ & $12.1 \pm 0.35$ & $14.4 \pm 0.66$ & $20.2 \pm 0.31$ \\
\hline Enterobacter aerogenes & $7.3 \pm 0.41$ & $11.2 \pm 0.22$ & $14.9 \pm 0.33$ & $19.5 \pm 0.40$ \\
\hline
\end{tabular}

Values are mean \pm SD, $n=3$. Results were analyzed using one-way ANOVA. SD: Standard deviation, ANOVA: Analysis of variance

Table 4: Activity of ethanol extract against urinary tract infected pathogens

\begin{tabular}{lllc}
\hline Isolates & \multicolumn{2}{c}{ Zone of inhibition (mm) } & Amoxicillin (250 mg) \\
\cline { 2 - 3 } & $\mathbf{1 0 0} \mathbf{~} \mathbf{~ g / \mathbf { ~ m }}$ & $\mathbf{1 5 0} \mathbf{~ m g} / \mathbf{m l}$ & $\mathbf{2 0 0} \mathbf{~ m g} / \mathbf{m l}$ \\
\hline Escherichia coli & $8.5 \pm 0.30$ & $11.3 \pm 0.14$ & $15.2 \pm 0.20$ \\
Pseudomonas aeruginosa & $10.2 \pm 0.22$ & $15.0 \pm 0.45$ & $20.1 \pm 0.26$ \\
Bacillus subtilis & $15.6 \pm 0.44$ & $19.8 \pm 0.10$ & $23.5 \pm 0.33$ \\
Enterobacter aerogenes & $11.2 \pm 0.56$ & $15.1 \pm 0.33$ & $17.4 \pm 0.21$ \\
Proteus vulgaris & $13.8 \pm 0.21$ & $16.8 \pm 0.15$ & $20.7 \pm 0.13$ \\
Staphylococcus aureus & $10.2 \pm 0.35$ & $13.1 \pm 0.56$ & $17.2 \pm 0.10$ \\
Klebsiella pneumoniae & $7.3 \pm 0.10$ & $9.1 \pm 0.53$ & $10.3 \pm 0.10$ \\
\hline
\end{tabular}

Values are mean \pm SD, $n=3$. Results were analyzed using one-way ANOVA. SD: Standard deviation, ANOVA: Analysis of variance

Table 5: Activity of aqueous extract against urinary tract infected pathogens

\begin{tabular}{|c|c|c|c|c|}
\hline \multirow[t]{2}{*}{ Isolates } & \multicolumn{3}{|c|}{ Zone of inhibition (mm) } & \multirow[t]{2}{*}{ Amoxicillin (250 mg) } \\
\hline & $100 \mathrm{mg} / \mathrm{ml}$ & $150 \mathrm{mg} / \mathrm{ml}$ & $200 \mathrm{mg} / \mathrm{ml}$ & \\
\hline Escherichia coli & $6.5 \pm 0.20$ & $8.3 \pm 0.22$ & $10.1 \pm 0.30$ & $18.4 \pm 0.24$ \\
\hline Pseudomonas aeruginosa & $10.2 \pm 0.11$ & $12.2 \pm 0.20$ & $15.1 \pm 0.44$ & $30.1 \pm 0.55$ \\
\hline Bacillus subtilis & $9.3 \pm 0.33$ & $12.5 \pm 0.44$ & $15.3 \pm 0.22$ & $22.3 \pm 0.11$ \\
\hline Enterobacter aerogenes & $10.1 \pm 0.22$ & $14.2 \pm 0.11$ & $16.1 \pm 0.11$ & $19.5 \pm 0.40$ \\
\hline Proteus vulgaris & $11.2 \pm 0.11$ & $15.2 \pm 0.33$ & $19.1 \pm 0.33$ & $20.2 \pm 0.31$ \\
\hline Staphylococcus aureus & $8.2 \pm 0.15$ & $12.1 \pm 0.55$ & $15.4 \pm 0.19$ & $20.0 \pm 0.31$ \\
\hline Klebsiella pneumoniae & $5.1 \pm 0.60$ & $7.0 \pm 0.13$ & $9.2 \pm 0.50$ & $13.5 \pm 0.20$ \\
\hline
\end{tabular}

Values are mean $\pm S D, n=3$. Results were analyzed using one-way ANOVA. SD: Standard deviation, ANOVA: Analysis of variance 
Table 6: Activity of ethanolic fractions against foot ulcer pathogens

\begin{tabular}{|c|c|c|c|c|}
\hline \multirow[t]{2}{*}{ Isolates } & \multirow[t]{2}{*}{ Fractions } & \multicolumn{3}{|c|}{ Zone of inhibition (mm) } \\
\hline & & $0.10 \mathrm{mg} / \mathrm{ml}$ & $0.15 \mathrm{mg} / \mathrm{ml}$ & $0.20 \mathrm{mg} / \mathrm{ml}$ \\
\hline \multirow[t]{2}{*}{ Staphylococcus aureus } & 1 & 4.5 & 8.8 & 12.1 \\
\hline & 3 & 3.3 & 6.5 & 6.9 \\
\hline \multirow[t]{3}{*}{ Escherichia coli } & 1 & 3.5 & 6.3 & 9.1 \\
\hline & 2 & 2.8 & 5.2 & 7.0 \\
\hline & 3 & 2.0 & 4.1 & 6.4 \\
\hline \multirow[t]{3}{*}{ Bacillus subtilis } & 1 & 4.9 & 8.1 & 11.2 \\
\hline & 2 & 4.1 & 6.3 & 9.6 \\
\hline & 3 & 3.5 & 4.9 & 7.3 \\
\hline \multirow[t]{3}{*}{ Pseudomonas aeruginosa } & 1 & 5.2 & 10.2 & 13.5 \\
\hline & 2 & 4.3 & 8.4 & 11.3 \\
\hline & 3 & 3.8 & 6.3 & 9.1 \\
\hline \multirow[t]{3}{*}{ Proteus vulgaris } & 1 & 4.3 & 8.3 & 11.0 \\
\hline & 2 & 3.7 & 6.9 & 8.9 \\
\hline & 3 & 3.1 & 5.5 & 6.4 \\
\hline \multirow{2}{*}{ Enterobacter aerogenes } & 2 & 3.5 & 6.4 & 8.2 \\
\hline & 3 & 2.9 & 5.5 & 7.1 \\
\hline
\end{tabular}

Values are mean, $\mathrm{n}=3$

Table 7: Activity of ethanolic fractions against urinary tract infected pathogens

\begin{tabular}{|c|c|c|c|c|}
\hline \multirow[t]{2}{*}{ Isolates } & \multirow[t]{2}{*}{ Fractions } & \multicolumn{3}{|c|}{ Zone of in,.hibition (mm) } \\
\hline & & $0.10 \mathrm{mg} / \mathrm{ml}$ & $0.15 \mathrm{mg} / \mathrm{ml}$ & $0.20 \mathrm{mg} / \mathrm{ml}$ \\
\hline \multirow[t]{3}{*}{ Escherichia coli } & 1 & 3.4 & 7.3 & 9.1 \\
\hline & 2 & 2.6 & 5.9 & 7.5 \\
\hline & 3 & 2.2 & 4.8 & 5.9 \\
\hline \multirow[t]{2}{*}{ Pseudomonas aeruginosa } & 1 & 6.9 & 11.3 & 15.4 \\
\hline & 2 & 5.4 & 9.4 & 13.2 \\
\hline \multirow[t]{3}{*}{ Bacillus subtilis } & 1 & 6.1 & 7.3 & 12.0 \\
\hline & 2 & 5.2 & 6.1 & 10.9 \\
\hline & 3 & 4.6 & 5.2 & 9.1 \\
\hline \multirow[t]{3}{*}{ Enterobacter aerogenes } & 1 & 4.8 & 10.2 & 11.9 \\
\hline & 2 & 4.0 & 8.8 & 10.4 \\
\hline & 3 & 3.6 & 6.5 & 9.3 \\
\hline \multirow[t]{2}{*}{ Proteus vulgaris } & 1 & 6.0 & 8.4 & 13.4 \\
\hline & 2 & 5.2 & 7.2 & 11.2 \\
\hline \multirow{2}{*}{ Staphylococcus aureus } & 2 & 2.9 & 7.4 & 10.4 \\
\hline & 3 & 2.4 & 6.3 & 9.0 \\
\hline \multirow[t]{3}{*}{ Klebsiella pneumoniae } & 1 & 2.5 & 4.3 & 6.3 \\
\hline & 2 & 1.8 & 3.8 & 5.1 \\
\hline & 3 & 1.2 & 2.9 & 4.4 \\
\hline
\end{tabular}

Values are mean, $\mathrm{n}=3$

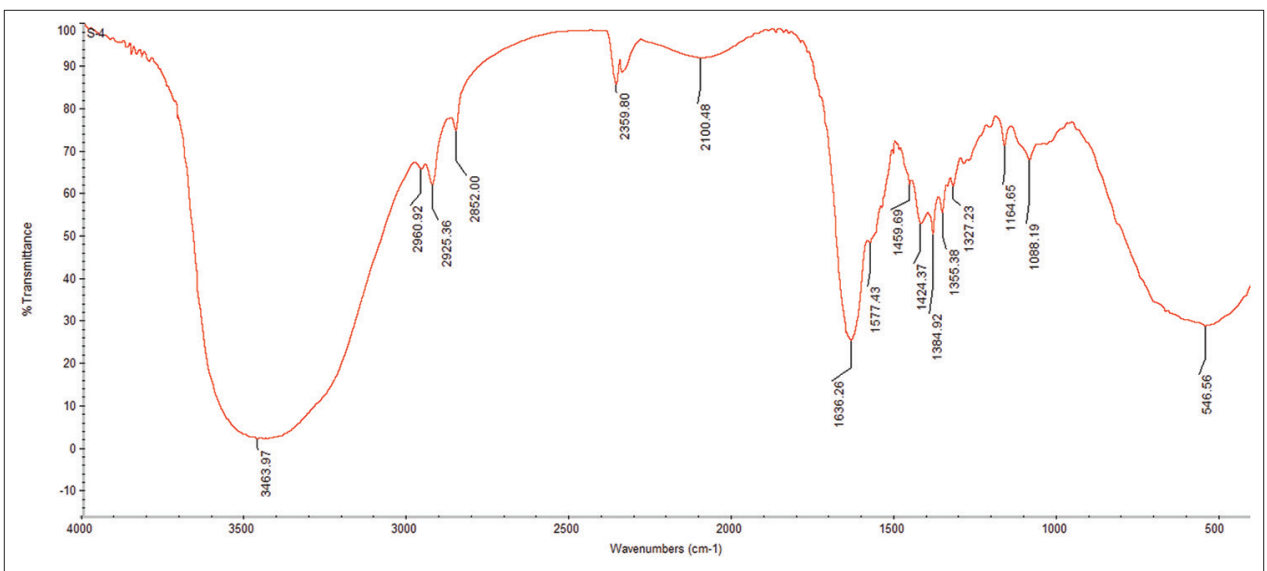

Fig. 1: Fourier-transformed infrared spectra of fraction one ethanolic extract of the leaves of the plant Aegle marmelos 
Table 8: Characteristics of infrared absorptions

\begin{tabular}{lll}
\hline Range $\mathbf{~ c m}^{-1}$ & Type of bond & Functional class \\
\hline 3463.97 & O-H stretch, H - bonded & Alcohols, phenols \\
2960.92 & C-H stretch & Alkanes \\
2925.36 & C-H stretch & Alkanes \\
2852.00 & C-H stretch & Alkanes \\
2100.48 & - C $=$ C - stretch & Alkynes \\
1636.26 & -N-H & Primary amines \\
1577.43 & C-C stretch (in ring) & Aromatics \\
1459.69 & C-H bond & Alkanes \\
1424.37 & C-C stretch (in ring) & Aromatics \\
1384.92 & N-O symmetric stretch & Nitro compounds \\
$1355.38(m)$ & N-O symmetric stretch & Nitro compounds \\
1327.23 & C-N stretch & Aromatic amines \\
$1164.65(m)$ & C-H wag (-CH X) & Alkyl halides \\
1088.19 & C-O stretch & Alcohols, carboxylic acids, \\
& & esters, ethers \\
546.56 & C-Br stretch & Alkyl halides \\
\hline
\end{tabular}

microbial strains. The previous study has revealed that aqueous and ethanolic extract of plant $A$. marmelos has activity against $P$. aeruginosa, $B$. subtilis, $S$. aureus, and E. coli. The ethanolic extract showed more activity to that of the aqueous extract. Elevated antimicrobial activity was shown against B. subtilis, followed by $S$. aureus, E. coli, and then $P$. aeruginosa [17]. Comparatively, in this study, $P$. aeruginosa $(22.5 \pm 0.26)$ exhibited the highest zone of inhibition and lowest was in E. aerogenes $(16.1 \pm 0.31)$ at the concentration of $200 \mathrm{mg} / \mathrm{ml}$ for foot ulcer pathogens, whereas urinary tract pathogens for ethanolic extract showed maximum inhibitory zone for B. subtilis $(23.5 \pm 0.33)$ and minimum zone of inhibition for $K$. pneumoniae $((10.3 \pm 0.10)$ at $200 \mathrm{mg} / \mathrm{ml}$

The ethanolic extract of $A$. marmelos was subjected for TLC and column chromatography. The TLC analysis of the methanolic extract of variety in Pant Aparna among all the varieties and accessions of $A$. marmelos in earlier studies detected the occurrence of phenolic compounds such as flavonoids and phenolic acids as the principal contributors to the scavenging effect $[18,19]$. Similar pattern of results was seen in ethanolic extract of leaves of $A$. marmelos plant with $\mathrm{Rf}$ value 0.94 , 0.81 , and 0.72 , respectively, and three different fractions were eluted from the column from which only fraction 1 strongly inhibited the urinary tract pathogens, i.e., P. aeruginosa showed the highest zone of inhibition $(15.4 \mathrm{~mm})$ whereas the lowest zone of inhibition was seen in $K$. pneumoniae $(6.3 \mathrm{~mm})$ at the concentration of $200 \mathrm{mg} / \mathrm{ml}$ and comparatively foot ulcer pathogens showed less inhibition.

In the previous study, the FT-IR spectroscopic study of $A$. marmelos L. unripe fruit powder showed the hydroxyl $(-\mathrm{OH})$, carboxyl $(-\mathrm{C}=0)$, and amine $(-\mathrm{NH})$ groups of coumarins, alkaloids, or tannins. Identification of functional groups in $A$. marmelos extract and its characterization through FT-IR, X-ray diffractometer visible spectrophotometer and atomic force microscopy [20], in this connection, parallel results were obtained from FT-IR spectroscopy which at different stretching vibrations were found to be alcohols, alkanes, alkynes, amines, nitroamines, phenols, aromatic, carboxylic acids, and ethers. The above reported bioactive compounds may have the potential to reduce the risk and growth of resistant foot ulcer and urinary tract infected pathogens and further, there is need of work to be done on mechanism and action of secondary metabolites to exploit their uses for medicinal purposes.

\section{CONCLUSION}

The ethanolic extract of $A$. marmelos plant showed good antimicrobial activity for both foot ulcers and urinary tract pathogens isolated from diabetic patients. Fraction 1 of the ethanolic extract exhibited the highest activity for urinary tract pathogens, i.e., for $P$. aeruginosa at the concentration of $200 \mathrm{mg} / \mathrm{ml}$. Thus, the findings suggest that $A$. marmelos had a potent antimicrobial activity. Further to confirm the activity structural elucidation studies should be carried out to confirm which bioactive compounds are responsible for the antimicrobial activity.

\section{AUTHORS' CONTRIBUTIONS}

The author declares that all the named authors have contributed equally to this article.

\section{AUTHORS FUNDING}

Financial support taken from University Grant Commission Maulana Azad National Fellowship with award letter number F1-17.1/2017-18/ MANF-2017-18-GOA-73835/(SAIII/Website).

\section{CONFLICTS OF INTEREST}

The authors declare that they have no conflicts of interest.

\section{REFERENCES}

1. Grover JK, Yadav S, Vats V. Medicinal plants of India with anti-diabetic potential. J Ethnopharmacol 2002;81:81-100.

2. Priyanka, Rita S. A systematic review on Indian floral biodiversity as eminent reserves for alternative treatment strategy of diabetes mellitus. Int J Pharm Pharm Sci 2016;8:10-9.

3. Eloff JN. Which extractant should be used for the screening and isolation of antimicrobial components from plants? J Ethnopharmacol 1998;60:1-8.

4. Bowler PG, Davies BJ. The microbiology of infected and noninfected leg ulcers. Int J Dermatol 1999;38:573-8.

5. Stapleton A. Urinary tract infections in patients with diabetes. Am J Med 2002;113:80-4.

6. Foxman B, Somsel P, Tallman P, Gillespie B, Raz R, Colodner R, et al. Urinary tract infection among women aged 40 to 65 : Behavioral and sexual risk factors. J Clin Epidemiol 2001;54:710-8.

7. Badam L, Bedekar SS, Sonawane KB, Joshi SP. In vitro antiviral activity of bael (Aegle marmelos Corr) upon human coxsackieviruses B1-B6. J Commun Dis 2002;34:88-99.

8. Porter IA, Brodie J. Boric acid preservation of urine samples. Br Med J 1969;2:353-5

9. Breed RS, Murray EG, Smith NR. Bergey's Manual of Determinative Bacteriology. Baltimore: The Williams and Wilkins Company; 1962.

10. Dubey RC. The Practical book of microbiology. $2^{\text {nd }}$ ed. New York: Times Books; 2007. p. 37-9.

11. Jerine PS, Evan PS. Global current trends in natural products for diabetes management: A review. Int J Pharm Pharm Sci 2016;8:20-8.

12. Anita P, Anthoni AS, Raj JS. In vitro antibacterial activity of Aegiceras corniculatum and Bruguiera cylindrica against isolated bacterial urinary tract infections. Int J Pharm Res Dev 2012;3:1120-5.

13. Rojas R, Bustamante B, Bauer J, Fernandez I, Albán J, Lock O. Antimicrobial activity of selected Peruvian medicinal plants. J Ethnopharmacol 2003;88:199-204.

14. Duraipandiyan V, Ayyanar M, Ignacimuthu S. Antimicrobial activity of some ethnomedicinal plants used by paliyar tribe from Tamil Nadu, India. BMC Complement Altern Med 2006;6:35

15. Parekh J, Chanda S. In vitro antimicrobial activity and phytochemical analysis of some Indian medicinal plants. Turk J Biol 2007;31:53-8.

16. Lakshmi SS, Chelladurai G, Suresh B. In vitro studies on medicinal plants used against bacterial diabetic foot ulcer (BDFU) and urinary tract infected (UTI) causing pathogens. J Parasit Dis 2014;40:667-73.

17. Venkatesan D, Karunakaran M, Kumar S, Palaniswamy P, Ramesh G. Antimicrobial activity of Aegle marmelos against pathogenic organism compared with control drug. J Ethnobot Leaflets 2009;13:968-74.

18. Francisco A, Harborne JB, editors. The Flavonoids Advances in Research Since 1986. Vol. 6. London, U.K: Chapman and Hall; 1995. p. 55.

19. Rice-Evans CA, Miller NJ, Bolwell PG, Bramley PM, Pridham JB. The relative antioxidant activities of plant-derived polyphenolic flavonoids. Free Radic Res 1995;22:375-83.

20. Krupa AN, Raghavan V. Biosynthesis of silver nanoparticles using Aegle marmelos (Bael) fruit extract and its application to prevent adhesion of Bacteria: A strategy to control microfouling. Bioinorg Chem Appl 2014;2014:1-8. 